\title{
Application of BIM Technology in practical teaching of Engineering Management Specialty
}

\author{
$\mathrm{Li} \mathrm{Li}^{1}$ \\ ${ }^{1}$ Xi'an FanYi University Xi'an, China
}

\begin{abstract}
At present, building information modeling is widely used in many stages of project life cycle. On the basis of combing the practical teaching of engineering management specialty, this paper analyzes the practice teaching conditions based on BIM Technology in application-oriented universities, and puts forward the construction measures of teaching system of BIM Technology in engineering management practice teaching.
\end{abstract}

\section{Introduction}

Building information modeling is a multi-dimensional model information integration technology developed on the basis of computer aided design. It mainly digitizes and visualizes the physical characteristics and related functional information of construction engineering. With the development of construction industry modernization, informatization has become one of its main characteristics. BIM Technology Application, as an important part of building informatization, is promoting the transformation of production mode in construction industry. In 2015, the Ministry of housing and urban rural development issued the guiding opinions on promoting the application of building information model. It is proposed that by the end of $2020,90 \%$ of the large and medium-sized construction projects with state-owned funds, public buildings and green ecological demonstration communities that declare green buildings should adopt integrated Bim in the aspects of survey and design, construction, and later operation and maintenance. Through the policy guidance of governments at all levels, enterprises occupy the dominant position in BIM application and promotion, and conduct demand traction. This also directly increases the demand for BIM talents, and the application-oriented colleges and universities which mainly serve the local economic development have a new direction and goal in the cultivation of engineering management professionals.

\section{The current situation of practice teaching of engineering management major}

The engineering management major in University of application-oriented is to cultivate high-quality applied talents who not only need to master the technical knowledge of civil engineering, but also have the basic knowledge of management, economy and law. After graduation, they can be engaged in project decisionmaking, engineering production and construction, and investment cost work. In the four-year training process, practical teaching is an inevitable way to improve students' professional application and practical ability. It is necessary to explore the construction of practice teaching system based on BIM Technology on the basis of traditional practice teaching.

Generally, the practice teaching of Engineering Management Specialty in Application-oriented Colleges and universities is divided into two parts: in class practice and centralized practice, in which centralized practice is mainly divided into two parts: on campus centralized practice and off campus professional practice. The on campus practice teaching is mainly carried out in the professional experimental training room, while the off campus practice is mainly carried out in the practice base. In class practice is mainly the experimental training to consolidate the theoretical knowledge and the application of curriculum knowledge in the learning process of theoretical courses. The concentrated practice is mainly the concentrated training for the improvement of students' professional comprehensive ability. Among them, professional practice is mainly for students to have a basic understanding of the major and basic knowledge and skills of the future work through field industry scene learning and related training. The practical teaching system of engineering management specialty is shown in Figure 1. 


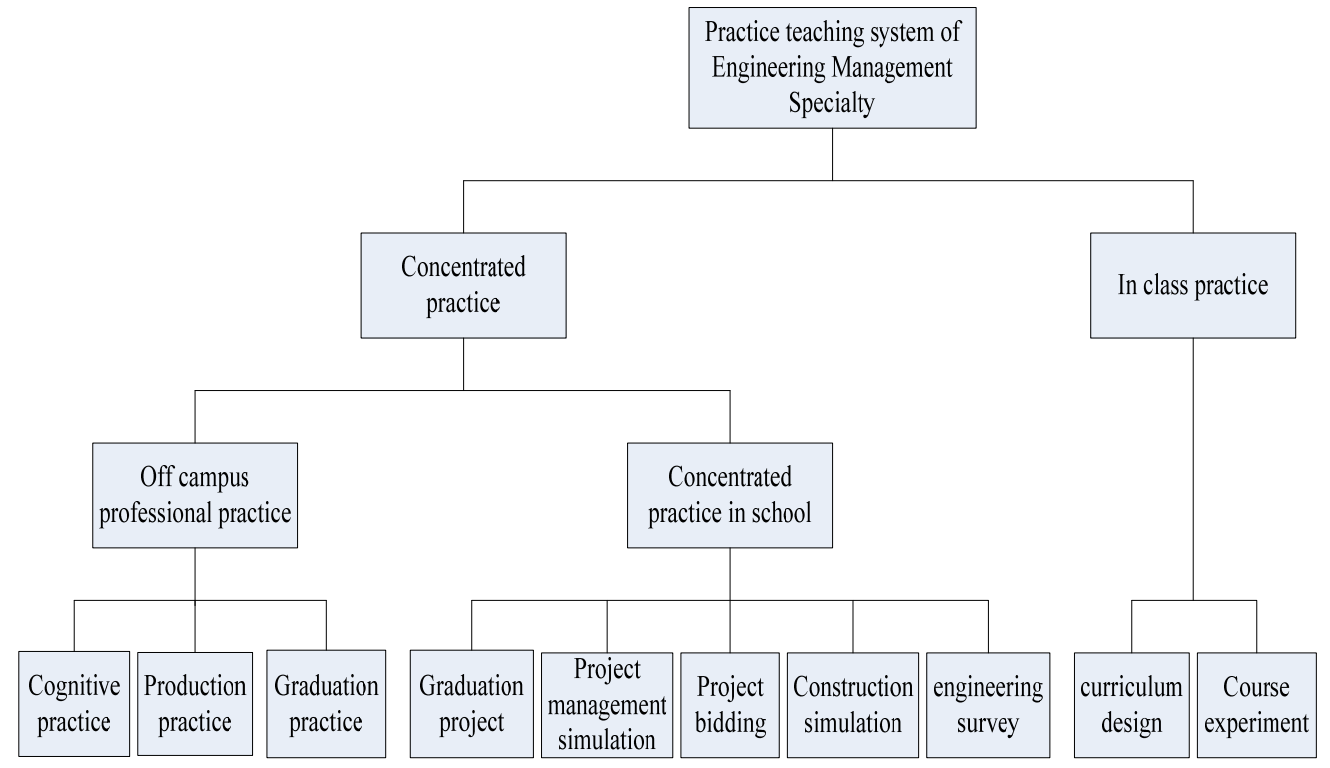

Figure 1. Composition of practice teaching system for Engineering Management Major.

Among them, the practice part of the course mainly includes "descriptive geometry and Engineering Drawing", "housing architecture", "engineering structure", "engineering economics", "civil engineering construction organization", and "Engineering Mechanics", "engineering survey", "civil engineering materials", "soil mechanics and foundation".

The three parts of practice teaching link is a progressive relationship from professional basic practice ability to special technical ability, and finally to professional comprehensive ability. However, the current practice teaching mainly focuses on the application and practice ability of traditional theoretical knowledge. Due to the wide range of knowledge distribution between courses and courses, as well as the constraints of various conditions of engineering projects, students cannot participate in the whole process of engineering projects Therefore, based on two-dimensional drawings, engineering management students lack a systematic and comprehensive understanding of the whole life cycle management of engineering projects. Due to the limitations of teachers, school information laboratory and so on, the informatization teaching of each link is insufficient. BIM Technology can simulate the construction process of a project on the basis of establishing a three-dimensional model of the project. After adding the information of progress and construction environment, it can continuously optimize the setting and seek the optimal scheme of construction organization and management.

\section{The conditions of applying BIM Technology to practice teaching}

BIM Technology can be effectively applied to the practical teaching of engineering management specialty, which needs the implementation of "combination of software and hardware". "Soft" refers to the construction of teaching staff based on BIM Technology, while "hard" refers to the software and computer configuration required by BIM
Technology.

\subsection{Construction of Teachers}

When BIM Technology is applied to practical teaching, it is necessary to ensure the teaching staff and reasonably allocate the teaching staff. At present, the teachers of practical teaching are mainly theoretical teachers, and some teachers mainly focus on theoretical knowledge, and they are not proficient in the application of BIM Technology. The faculty can be built by the way of "going out and bringing in". "Going out" refers to organizing professional teachers to participate in BIM software operation and application training and learning activities in cooperative enterprises or related software companies, so as to first improve teachers' BIM application skills; "introduced" refers to directly introducing mature BIM technical talents from relevant enterprises as part-time practical teachers; enriching the teaching staff of professional practice teaching through these two ways.

\subsection{Construction of Experimental Training Room}

BIM Technology, as an integrated technology of modern engineering project information technology, needs highperformance computer configuration, as well as the collaborative work of a variety of professional software, and build a virtual simulation platform. Only by using BIM Technology can we sort out and summarize the information of survey and design, bidding, construction, operation and maintenance of engineering projects, and then carry out effective engineering management related work. Therefore, based on the configuration of highperformance computer training room, colleges and universities need to purchase and install modeling software, virtual simulation software, project management software and other major software, and build BIM Technology Experimental Training platform. 


\section{Construction of professional practice teaching system based on BIM Technology}

\subsection{Teaching Objectives}

The core of BIM Technology is that through the establishment of building information model, the information of each stage of the whole life cycle of engineering construction project can be dynamically, stereoscopically and visually displayed to all participants of the project. Practice teaching is an inevitable way to cultivate applied talents and improve students' practical ability. The overall goal of practice teaching based on BIM Technology is to improve students' BIM Technology application skills. After students master the operation of modeling software, construction simulation software and construction project management software, the teaching objectives of each part of the practical teaching link are set according to the principle of progressive ability and theoretical teaching. Improve students' application ability to solve practical engineering problems through the application of BIM Technology on the basis of mastering theoretical knowledge.

\subsection{Tteaching Content Design}

\subsubsection{BIM technology basics}

The information and data of the whole life cycle of engineering projects are stored by BIM Technology. Through the explanation of basic theories, students can have a basic understanding of the big information system of BIM Technology and master the basic theoretical knowledge. Combined with the 3D modeling software, construction simulation software, construction project management software and electronic bidding software used by BIM Technology, specific software operation explanation and practice are carried out.

\subsubsection{Basic application of BIM Technology}

\subsubsection{Practical teaching of basic skills}

The training of basic skills is mainly based on the theory of technical courses of engineering management, taking descriptive geometry and engineering drawing, housing architecture and civil engineering construction as examples.

"Descriptive geometry and Engineering Drawing" course is mainly to cultivate students' spatial imagination thinking ability, spatial analysis ability, master the basic drawing methods, and have certain ability to read and read drawings. The traditional manual drawing and CAD drawing are only limited to two-dimensional plane, so students lack of intuitive three-dimensional sense of architecture. In the practical teaching part of the course, traditional students can effectively combine the modeling software of BIM Technology to carry out 3D modeling on the basis of mastering 2D drawing drawing drawing. It can not only enhance students' practical sense of engineering, but also help to check the correctness of drawing through the presentation of 3D model of building which stores various information.

"Housing architecture" course mainly establishes a complete concept of housing construction. Students can master the relevant knowledge of building construction and have the preliminary ability of general architectural design. The traditional curriculum design of classroom teaching is mainly based on the drawing of twodimensional drawings. Students lack a certain sense of space and three-dimensional for the designed buildings or components. On this basis, the use of BIM Technology through the three-dimensional modeling software for the three-dimensional visualization of the building, through the building constraints and environmental information data input, the details of the design scheme can be preliminary error detection, help to determine the optimal scheme.

"Civil engineering construction" course mainly requires students to master the basic construction process, construction technology and main technical methods of civil engineering. Due to the lack of on-site operation experience, the understanding of the specific construction process and construction equipment mainly depends on the description in books. In the practical teaching part of the course, the application of virtual construction simulation software is introduced to simulate the construction site operation. Each process and each operation are simulated by students, so that students can participate in the whole process from earthwork excavation to project completion, consolidating theoretical knowledge and improving the practical application ability of the project.

\subsubsection{Practical teaching of professional applied skills}

The promotion of professional application skills mainly relies on comprehensive professional courses and concentrated practice links, taking "sand table simulation of project management" and "project bidding and contract management" as examples.

"Sand table simulation of engineering project management" takes sand table as the carrier to construct a simulation market competition environment of construction project management. The construction project is "moved" to the school classroom, the complex and abstract construction project management theory is presented in an intuitive way, and the students involved are given different management roles. Through the simulation of the construction site, the human resources, materials, machinery, capital, business process of the construction unit are decided by the simulation role, so as to complete a virtual engineering project from signing the contract to the completion of the project. Compared with traditional learning, sand table has provided a relatively intuitive construction scene. If BIM Technology is introduced to multi-dimensional engineering information in sand table, model construction from model to cost 
control, schedule control and other dimensions will be closer to the actual project and improve students' practical professional application skills.

"Project bidding and contract management" requires students to master the basic bidding procedures, have the ability to prepare bidding documents and bidding documents, and be familiar with the key points of contract management. The traditional design results are mainly to prepare bidding documents. In the process of preparation, students will comprehensively use the knowledge of engineering list valuation, engineering construction organization, construction technology, project management, etc., but it is difficult for students to master comprehensively due to the wide range of knowledge and many knowledge points involved. The introduction of BIM Technology, through the application of electronic bidding software, all the involved links of software will be fully included, the process is clear, many standard complex parts in the process of document preparation can be automatically generated format, students can complete and clearly grasp the basic knowledge of engineering bidding, and quickly improve their ability.

\subsubsection{Improvement of comprehensive application ability}

The comprehensive application ability is mainly through the graduation project and unit practice to cultivate and improve the students' comprehensive ability in four years' study.

Graduation project is a comprehensive professional training for students before they go to work after learning professional theoretical knowledge. It is a summary training of four years' study. In order to meet the needs of enterprises for BIM technical talents, BIM Technology is introduced into graduation design. For example, "engineering construction organization" topic selection, the traditional design results are to combine a completed project to carry out the preparation of unit engineering construction organization design. Due to the limited available resources of teachers and students, students cannot have a comprehensive and intuitive understanding of the project only through document preparation. After the introduction of BIM Technology, through the input of construction site, construction schedule, cost, resources and other information data, a multi-dimensional project management model is formed on the basis of threedimensional model. Let students change from static file content to master the comprehensive dynamic management of engineering site, so as to improve the comprehensive application ability.

\subsubsection{Systematization of teaching content}

Due to the limitation of traditional practice teaching conditions, each training is carried out for a single training purpose, which results in fragmented learning of project life cycle management required by engineering management specialty. After the introduction of BIM Technology, we can use the powerful information storage function of BIM Technology to set up the practice teaching content systematically, that is to use a specific project to set the practical requirements in the decision-making stage, design stage, bidding stage, construction stage and operation and maintenance stage of the project life cycle, and each training is conducted according to the project stage Practice application, let students through a complete project task to complete the progressive improvement of practical skills, and then also enhance the BIM Technology Application practical ability.

\subsection{Design of Teaching Methods}

On the basis of mastering theoretical knowledge, students should also be proficient in operating software, so it is necessary to enhance students' autonomous learning link. Combined with BIM Technology, a typical project task is created, and the training is carried out in the form of project team driven by task. After the training is completed, the group will dynamically display and explain the actual training results to stimulate students' interest in learning and improve their practical application ability.

\subsection{Teaching Evaluation}

Different from the teaching evaluation of theoretical teaching, the goal of practical teaching is to improve students' application ability. With ability testing as the main means, it can be evaluated through professional competition and enterprise application.

\subsubsection{Promoting learning through competition}

Skills competition is an effective way to improve students' practical ability. It can not only promote students' proficient operation of software, but also improve their professional comprehensive application ability and strengthen their professional quality. At present, most schools achieve the goal of "promoting teaching and learning through competition" by encouraging students to participate in professional competitions. Due to the limited number of participants in the off campus competition, the main way is to stimulate students' interest in learning and improve their practical ability. According to the needs of enterprises for BIM technical talents, combined with the assessment scope of off campus competition, relying on professional theoretical courses, based on BIM Technology, we carry out architectural drawing competition, building model competition, engineering bidding document preparation competition, BIM modeling competition and engineering construction organization competition. In the process of designing and organizing professional competitions, teachers can reflect on the practical teaching design and promote the better development of practical teaching. Through the selection of different levels of competition inside the school, students learn from the competition, forming a good learning atmosphere, and also reserve candidates for the competition outside the school. 


\subsubsection{Promoting learning through competition}

As the direct application subject of BIM Technology, the application of BIM Technology is mature, and the recognition of talents by enterprises is a strong evidence to achieve the training goal of applied talents. To strengthen the school enterprise cooperation, on the one hand, we can use the advanced technical personnel of enterprises to carry out BIM Technology Training for school teachers, strengthen the temporary training of young teachers, and increase the engineering practice experience of teachers; at the same time, the engineering projects of enterprises provide favorable places for students from computer simulation to engineering field practice, and the project experience of enterprises also provides sufficient practical engineering data for practical teaching. Through the students' practical engineering practice, the problems are found and solved, and the practice teaching in school is adjusted dynamically. At the same time, the teaching effect of students' learning BIM Technology is effectively evaluated.

\section{Conclusion}

In the current era of information technology development, the demand for BIM Technology Talents is increasing. Engineering management major is a comprehensive discipline which integrates engineering technology, management, economy and legal knowledge and ability. The application of BIM Technology is conducive to the improvement of students' comprehensive ability. Based on BIM Technology, the practical teaching system of engineering management specialty should be reasonably constructed to improve students' BIM application skills, enhance their professional quality, effectively connect with the industry demand, and cultivate high-quality application-oriented talents. High quality talents can enhance the influence of the University, promote the longterm development of the school, and better serve the local economy. Therefore, the reasonable construction of the practical teaching system based on BIM Technology is the exploration direction of the development of engineering management major in application-oriented universities.

\section{Acknowledgment}

I would like to express my sincere thanks to the schoollevel experiment teaching demonstration center and virtual simulation experiment teaching center program of Xi'an FanYi University in 2019, "Engineering Management Experimental Teaching Demonstration Center"(Z1901) and the teaching reform research project of Xi'an FanYi University in 2020“Application and practice of situational interactive classroom in project management teaching "(J20A05)for their financial support for this paper.

\section{References}

1. Dai Xiaoyan; Liu Chao. "Practice teaching reform of Engineering Management Specialty for new engineering colleges,"J. Laboratory Research and Exploration, 2019, v.38; no.286,pp.229-232 + 236 .

2. Zhang Li. "Research on practice teaching reform of engineering management specialty group based on "integration of competition and education","J. Anhui Architecture, 2020, v.27; no.239,pp.171-172.

3. Jing min; Liu Yangbing. "Research on BIM based practical teaching system,'J. Education and teaching forum, 2020, no.456,pp.288-289.

4. Liu Jianxin. "Practice teaching reform of Engineering Management Specialty Based on application-oriented talent cultivation,'J. Journal of Hulunbeier University, 2020, V.28; no.140,pp.145-148. 